\title{
THE ENTREPRENEURIAL INTENTIONS OF TOURISM AND HOSPITALITY STUDENTS IN THE FACE OF THE COVID-19 PANDEMIC
}

\author{
Christian Stipanović \\ Elena Rudan \\ Vedran Zubović
}

https://doi.org//10.20867/tosee.06.48

\begin{abstract}
Purpose - Unfavorable conditions in the macro environment (Covid-19, economic crisis, depopulation) pose new challenges to the tourism industry and thus to the training of future tourism professionals. The aim of this paper is to explore the level of entrepreneurial intention of students at the Faculty of Tourism and Hospitality Management in Croatian tourism in response to the modern environment (analysis of the influence of the environment on the level of entrepreneurial intention).

Methodology - The paper investigates the entrepreneurial intentions and skills of students of the Faculty of Tourism and Hospitality Management. The research, using a questionnaire based on a sample of 323 undergraduate students, shows the motivation factors of the entrepreneurial intentions in the context of the Covid-19 pandemic. Exploratory factor analysis is used to establish four levels of motivation to pursue entrepreneurial activity.

Findings - The theoretical level of research analyzes the influence of unfavorable macroeconomic conditions on tourism and their impact on students' entrepreneurial intentions. Existing research mainly focuses on personal challenges which provides the greatest incentive to start a new business. The influence of the social and societal environment is playing the most important role according to the research results.

Contribution - The article determines the level of entrepreneurship of students in tourism who need to develop their skills in a practical sense. The study can be extended to under-graduate students and compared with similar studies conducted in other tourism and hospitality faculties to determine entrepreneurial intention.
\end{abstract}

Keywords: entrepreneurship, entrepreneurial intentions, Covid-19, student, exploratory factor analysis.

\section{INTRODUCTION}

Entrepreneurship is a fundamental driver of the economic development and growth of any country. Focusing education on, and creating an environment conducive to, the development of entrepreneurial initiative is especially important for young people, students in particular. The entrepreneurial initiatives and innovativeness of students need to be encouraged and built upon to create a foundation for fostering the entrepreneurial activities of young people, especially in Croatia, a country faced with the exodus of its working-age population. To this end, providing economics-based entrepreneurship education is vital but it is equally important to establish exactly how powerful are the incentives of the environment impacting students' motivations to engage in entrepreneurial initiatives, and how interested are students in self-employment. Clearly, 
ToSEE - Tourism in Southern and Eastern Europe, Vol. 6, pp. 725-737, 2021.

C. Stipanović, E. Rudan, V. Zubović: THE ENTREPRENEURIAL INTENTIONS OF TOURISM AND ...

there are a number of different factors at work here, such as inheriting a family business, the effects on entrepreneurship of state and public administration, policies, the Covid-19 pandemic, and other external factors that impact on creating opportunities and enabling or constraining students' entrepreneurial initiatives. During their studies, students are provided different ways of learning and acquiring entrepreneurial knowledge (for example, through case studies and team work; by incorporating entrepreneurs as lecturers in the teaching process; studying the work of entrepreneurs, completing project tasks, etc.). Another vital element is the environment, and how not to see change and challenges as a threat but rather as an opportunity.

Accordingly, the following research questions were formulated, focusing on the entrepreneurial intention of final-year undergraduate students at the University of Rijeka's Faculty of Tourism and Hospitality Management:

1. What elements affect the entrepreneurial intention of tourism and hospitality students?

2. Is the COVID-19 pandemic affecting the entrepreneurial intention of students?

\section{LITERATURE REVIEW}

The many studies exploring the various aspects of entrepreneurship and the problem of its definition (Gartner 1990; Shane 2003; Škrtić 2011; Mishra and Zachary 2015) indicate that entrepreneurship is actually a process through which individuals, given their managerial, organization, innovational, and other skills, seek to create new value. In this process, they are willing to take business risks as well as dealing with threats in an uncertain environment.

Today universities are no longer positioned as institutions of higher learning only but are seen as one of the key factors of technological development, competitiveness, and economic progress (Bilić, Škokić and Lovrinčević 2021). Synergy between higher education, the economy, and policies is crucial in creating a country's entrepreneurial basis. To develop entrepreneurship, the Triple Helix concept encourages actors (universities - governments - businesses) to operate in an open space in which aspirations, knowledge, and innovation circulate freely (Singer, Oberman and Peterka 2012). Despite there being no consensus as to whether entrepreneurship can be fostered through education, much of the literature on this issue recognizes the positive contribution of entrepreneurial education in developing human knowledge and skills and in strengthening entrepreneurial mindsets and intentions. With regard to the integration of entrepreneurial education into higher education, universities of the twenty-first century can become vital engines of technological development and economic growth (Boldureanu 2020). Improving the effectiveness and relevance of education can help to create a space conducive to entrepreneurial objectives (Naveed Iftikhar, Ahmad and Audretsch 2020; Oberman Peterka 2011). The European Commission (2021) also highlights the importance of entrepreneurship education, pointing out that entrepreneurship is a valuable skill for the personal and professional development of EU citizens. Entrepreneurship education is vital to ensure the competitiveness and steady 
ToSEE - Tourism in Southern and Eastern Europe, Vol. 6, pp. 725-737, 2021.

C. Stipanović, E. Rudan, V. Zubović: THE ENTREPRENEURIAL INTENTIONS OF TOURISM AND ...

growth of the economy. Entrepreneurship-focused education helps to generate entrepreneurial initiatives in students, but there are also other factors that have a significant impact on such initiatives. Entrepreneurship education has an important role in creating individuals capable of dealing with the complexity and uncertainty of the environment in which they must operate. It helps individuals to become proactive, innovative and responsible, and willing to take risks in decision making and problem solving. Entrepreneurship education promotes the integration of different scientific disciplines and facilitates the development of skills needed for a multidisciplinary approach to solutions (Oberman Peterka, Singer and Alpeza 2013). Growing interest in entrepreneurship in world economies is also drawing attention to drivers, such as intentions, traits, behavioral patterns, and external and contextual factors, that lead individuals to become entrepreneurs (Daim 2016). These drivers are also studied in the student population.

In their study, Arranz, Arroyabe and Fdez de Arroyabe (2019) underline that students' capacities and desire for personal fulfilment influences their entrepreneurial intention to a much greater extent than training received in a university context. The authors also suggest that in addition to transferring knowledge about the entrepreneurial process, educational programs need to be designed to boost certain personality traits, including the need for self-fulfillment and risk-taking, as these characteristics can be seen as essential factors impacting the development and delivery of a business project.

Entrepreneurship drives change based on creative ideas to transform resources in making innovations (the highest level of competitive advantage) to generate new value. Speed and innovation separate successful companies from unsuccessful ones in the increasingly turbulent and challenging market. It should be the task of universities to guide students in generating new solutions by helping them develop their vision, leadership abilities and creativity to actively create the future. To this end, universities, together with businesses, should seek to continuously innovate entrepreneurship study programs (an example is Project E4 - Excellence and effectiveness in higher educations in the field of economics, 2019-2022, aimed at improving the quality, relevance and effectiveness of higher education through the development and use of sophisticated learning and teaching methods, and the innovations of graduate programs in the field of entrepreneurship proposal for the qualification Master of Business Economics in Entrepreneurship).

The environment also has a very important impact on entrepreneurial behavior. It consists of a number of factors that create different conditions for developing entrepreneurial activity. These factors include institutions, regulations, laws, policies, etc. (Farzin et al. 2014). The obstacles with the greatest adverse impact on entrepreneurial intention are the lack of funding, the lack of experience, and the lack of knowledge about the market (Arranz et al. 2019).

In early 2020, the world economy experienced its greatest challenges in recent decades as a result of the global health crisis caused by the COVID-19 pandemic. The pandemic has affected the lives of people in many ways, including the lives of students, suddenly preventing them from actively socializing with their generation and turning them into individuals who communicate with the world and take their courses in an online 
ToSEE - Tourism in Southern and Eastern Europe, Vol. 6, pp. 725-737, 2021.

C. Stipanović, E. Rudan, V. Zubović: THE ENTREPRENEURIAL INTENTIONS OF TOURISM AND ...

environment. The Covid-19 pandemic has not only brought numerous changes to the way students live but also to the way they think about the future.

\section{METHODOLOGY}

Research was conducted at the University of Rijeka's Faculty of Tourism and Hospitality Management to identify the entrepreneurial intentions and skills of final-year undergraduate students and to determine how the level of entrepreneurial intention in the Croatian economy is affected by the reasons for starting a business, the social and business environment, and the factors of employability in existing organizations. Special emphasis was placed on exploring the students' entrepreneurial intentions, given the challenges brought on by the Covid-19 pandemic.

\subsection{Hypotheses}

In accordance with the aims of the research, the following hypotheses were formulated:

H1: The environment (economic, political, social and societal) is a statistically significant predictor of students' entrepreneurial intentions

H2: Intrinsic motivation (challenge, self-actualization) of students is a better predictor for entrepreneurial initiatives than external motivations (profit, family environment)

H3: The Covid-19 pandemic is perceived as an obstacle to the realization of entrepreneurial initiatives.

\subsection{Data collection and research framework}

Data collection was carried out in February and March 2021 on the total population of 323 final-year students.

The respondents were orally informed during classes and additionally by email about the survey and given brief information about its objectives, as well as a link to the questionnaire available via the Internet. The response rate was 33.1\% (107 students).

Questionnaires that were not completely filled out were excluded from the sample. Of the 107 respondents, 35 (32.7\%) stated that upon graduating they intend to look for work outside of Croatia. The questionnaires of these 35 respondents were not taken into consideration for further analysis, as the survey ended for them with their affirmative response to that question. This means the sample for further processing dropped to 72 respondents. Most of the respondents were between 22 and 23 years old (69.2\% or 74 students) and female (63.6\% or 68 students). As the Faculty provides full-time and parttime courses, full-time students accounted for $48.6 \%$ of the sample (52 students) and part-time students, for $51.4 \%$ (55 students). 
ToSEE - Tourism in Southern and Eastern Europe, Vol. 6, pp. 725-737, 2021.

C. Stipanović, E. Rudan, V. Zubović: THE ENTREPRENEURIAL INTENTIONS OF TOURISM AND ...

\subsection{Measurements validation}

The survey used an adapted questionnaire of students' entrepreneurial intention (Qiao, and Huang, 2019), and a modified version of the instrument developed by Krueger (2000), Hassan (2012) and Langkamp Bolton and Lane (2012). The entrepreneurial intention, focused on the possibility of respondents launching their own entrepreneurial initiatives. Propensity for entrepreneurial initiatives was measured using three constructs: attitudes towards achieving one's goals (two statements), attitudes towards profit (two statements), and attitudes towards personal challenge (two statements).

The questionnaire comprised 35 items, divided into 5 dimensions:

1. Demographic profile

2. Social background, with respondents rating the possibility of being employed by parents, friends or relatives distributed across 3 variables

3. Entrepreneurial intention, focused on the possibility of respondents launching their own entrepreneurial initiatives distributed across 4 variables

4. The effect of Covid-19 on entrepreneurial intention, with respondents rating constraints to realizing their entrepreneurial initiatives distributed across 3 variables

5. Competences and knowledge acquired during studies, with respondents rating the adequacy of the knowledge and skills acquired during studies in helping them launch their own entrepreneurial initiatives distributed across 3 variables.

In parts of the questionnaire a Likert scale was used, ranging from 1 (strongly disagree) to 5 (strongly agree). The respondents who reported they want to start their own business or get a job in an existing business run by family, friends or relatives were asked to continue with the questionnaire. Thus, 48 students $(44.6 \%)$ were qualified to take the rest of the survey, the results of which were further analyzed. The scale for entrepreneurial motivation was taken from Parreira et al. (2018). Exploratory factor analysis was used to establish four levels of motivation to pursue entrepreneurial activity: societal and social background, profit, prestige, and personal development. Confirmatory factor analysis revealed good indicators: $(\mathrm{NFI}=.806, \mathrm{CFI}=.810, \mathrm{TLI}=.868$, and $\mathrm{RMSEA}=.080)$.

Table 1: Analysis of main components of perceived entrepreneurial intention

\begin{tabular}{|c|c|c|c|}
\hline Components & $\begin{array}{l}\text { Economic } \\
\text { environment }\end{array}$ & $\begin{array}{l}\text { Social and societal } \\
\text { environment }\end{array}$ & $\begin{array}{c}\text { Political } \\
\text { environment }\end{array}$ \\
\hline $\begin{array}{l}\text { Current state of economic } \\
\text { development }\end{array}$ & 0.856 & 0.413 & \\
\hline $\begin{array}{l}\text { The current environment for market } \\
\text { competition is conducive } \\
\text { to entrepreneurship }\end{array}$ & 0.842 & 0.503 & \\
\hline $\begin{array}{l}\text { Parents and relatives are supportive of } \\
\text { entrepreneurial } \\
\text { initiative }\end{array}$ & & 0.824 & \\
\hline
\end{tabular}


ToSEE - Tourism in Southern and Eastern Europe, Vol. 6, pp. 725-737, 2021.

C. Stipanović, E. Rudan, V. Zubović: THE ENTREPRENEURIAL INTENTIONS OF TOURISM AND ...

Table 1 (continued)

\begin{tabular}{|c|c|c|c|}
\hline Components & $\begin{array}{c}\text { Economic } \\
\text { environment }\end{array}$ & $\begin{array}{c}\text { Social and societal } \\
\text { environment }\end{array}$ & $\begin{array}{c}\text { Political } \\
\text { environment }\end{array}$ \\
\hline $\begin{array}{l}\text { Competencies acquired at the Faculty } \\
\text { provide the knowledge needed to pursue } \\
\text { entrepreneurial initiative }\end{array}$ & & 0.874 & \\
\hline $\begin{array}{l}\text { Public administration authorities have } \\
\text { created a good environment } \\
\text { for starting a business }\end{array}$ & & & 0.918 \\
\hline $\begin{array}{l}\text { Local government and self- government } \\
\text { have created an enabling environment for } \\
\text { starting a business }\end{array}$ & & & 0.932 \\
\hline Cronbach's $\alpha$ & 0.798 & 0.863 & 0.893 \\
\hline
\end{tabular}

Source: Authors' own elaboration.

The saturations of individual aspects of the obtained dimensions are shown (saturations lower than 0.3 are not shown; Orthogonal Varimax dimensional rotation was used). Exploratory factor analysis (Table 1) showed that motivation to pursue entrepreneurial activity items are grouped into: economical environment, societal and social environment and political environment. It should be noted that the economic and societal and social environment partly overlap, as evidenced by the relatively high saturations of perception of the current situation of economic development and the current competition environment, which are related to both the economic and societal and social. The societal and social environment is additionally connected with the personal environmental support and competences and knowledge acquired during studies. On the other hand, the dimension of the political environment is related to the perception of public and local government support in encouraging entrepreneurship.

Measurement scales derived from the obtained components (economic, social and societal and political environment) demonstrated discriminant validity and reliability. Cronbach's alpha coefficients were almost 0.8 for the economic environment scale, and more than 0.8 for the other two scales.

\section{FINDINGS AND DISCUSSION}

Yao et al. (2016) highlited that if the economy is developing rapidly and market has more gaps, the number of people who choosing self-employment may increase. Moreover, entrepreneurship is the most direct way of innovation, university students as a young group of the most innovative potential, have stronger entrepreneurial ability.

\subsection{Student entrepreneurial initiatives}

Respondents were asked to answer what are their intention after graduation. Most of the respondents $(42.1 \%$ or 45 students) reported wanting to find a job with a private employer, and $23.3 \%$ (25 students), in a public or state enterprise. Twenty-two students 
ToSEE - Tourism in Southern and Eastern Europe, Vol. 6, pp. 725-737, 2021.

C. Stipanović, E. Rudan, V. Zubović: THE ENTREPRENEURIAL INTENTIONS OF TOURISM AND ...

(20.6\%) stated they want to start their own business, and 15 students (14\%) reported they do not know or do not have any plans for their future employment. Full-time students with no previous work experience largely reported (34.6\% or 18 students) they would like to find a job with a private employer, and only $15.4 \%$ or 8 students would like to start their own business. Fourteen part-time students $(25.5 \%)$ stated they want to start their own business. The results of this part of the study are as expected, considering that part-time students have more work experience and are more prepared to start their own business given their acquired competencies.

Of the 48 students in the final sample, who gave a positive response to the question of whether they would like to start their own business or get a job in an existing business run by family, friends or relatives, almost half of them (45.6\% or 22 students) reported that they have no opportunities for employment with family, friends or relatives. Of the respondents $(54.4 \%$ or 26 students) who have opportunities for employment in the existing private sector businesses of their family/friends/relatives, most of these opportunities are in limited liability companies (53.9\% or 14 students). Previous studies show that entrepreneurial tendencies are greater in individuals whose parents were entrepreneurs (Chlosta et al. 2012; Staniewski and Awruk 2021).

The question of entrepreneurial initiatives was used as a dependent variable for testing the hypotheses. Data analysis confirms there is a difference in entrepreneurial intention based on gender, full-time/part-time student status, and age. Students of the male population exhibit greater independent entrepreneurial intention. Previous research also suggests that female students have a less positive attitude towards entrepreneurship and a desire to start their own business (Dickel and Eckardt 2021; Kourilsky and Walstad 1998). A study by the Financial Agency (FINA 2019) shows that the share of companies in Croatia founded solely by women ranged from $17.3 \%$ in 2010 to $22.0 \%$ in 2018 .

\subsection{Dimensions of the environment and entrepreneurial initiatives of students}

In order to test the first hypothesis about the relation between the environment and student entrepreneurial initiatives, a linear binary regression was performed with student entrepreneurial initiatives as a criterion variable (since this variable is dichotomous: there is or is no entrepreneurial initiative the binary regression analysis was performed). Scales of three types of environment were used as predictor (independent) variables: economic, social and societal and political environment. The table below shows the obtained regression coefficients, with indications of statistical significance.

Table 2: Standardized regression coefficients, $\beta$ with corresponding measures of statistical significance (t-ratio and $p$ value) for environmental dimensions as predictor variables and entrepreneurial initiatives of students as a criterion variable

\begin{tabular}{lccc}
\hline Envirionment dimension & $\beta$ coefficient & $\mathrm{t}-$ value & $\mathrm{p}$ \\
\hline Economic environment & 0,249 & 7,25 & 0,032 \\
Social and societal environment & 0,304 & 8,32 & 0,001 \\
Political environment & 0,204 & 6,36 & 0,041 \\
\hline
\end{tabular}

Source: Authors' own elaboration. 
ToSEE - Tourism in Southern and Eastern Europe, Vol. 6, pp. 725-737, 2021.

C. Stipanović, E. Rudan, V. Zubović: THE ENTREPRENEURIAL INTENTIONS OF TOURISM AND ...

The presented results show that all three dimensions of the environment are statistically significant predictors of entrepreneurial initiatives, which confirms hypothesis 1 . In addition, it should be noted that the social and societal environment that includesfamily support and educational component is a predictor with the highest regression coefficient, which indicates a greater "impact" of this type of environment on entrepreneurial initiatives. The economic environment is a mediator of entrepreneurial initiatives, while the political environment is the weakest of the three tested environments, although it is statistically significant.

\subsection{Entrepreneurial motivations of students}

Essentially, entrepreneurial motivation refers to the internal and external urges or desires of an individual to pursue entrepreneurial activities. This implies that entrepreneurial motivations can be categorized as internal and external motivations. Internal motivation is an individual's desire to find their own space within the competitive business environment, driven by the need for self-actualization and achievement. On the other hand, external motivations are linked to family influence and academic influence (Melugbo et al. 2020), in addition to the overall environment (political, administrative, and epidemiological).

As part of the testing of the second hypothesis, a linear regression analysis was used for predicting entrepreneurial intent of students as a criterion variable, and personal challenge, attitude towards profit and attitude towards personal goals as predictor variables. The conducted analysis of motivations shows three very significant relationships of entrepreneurial intentions, as stated in Table 3.

Table 3: Standardized regression coefficients, $\beta$ with corresponding measures of statistical significance ( $t$-ratio and $p$ value) for student motivation dimensions as predictor variables and entrepreneurial initiatives of students as a criterion variable

\begin{tabular}{lccc}
\hline Envirionment dimension & $\beta$ coefficient & $\mathrm{t}-$ value & $\mathrm{p}$ \\
\hline Self-actualization & 0,378 & 9,78 & 0,001 \\
Profit & 0,201 & 6,11 & 0,046 \\
Goals & 0,224 & 6,52 & 0,039 \\
\hline
\end{tabular}

Source: Authors' own elaboration.

The intention of students to start their own business is largely related to personal challenge as motivation. Although the relationship to profit and goals are also statistically significant predictors, personal challenge has the highest predictive validity for entrepreneurial initiative.

The intention of students to start their own business is based on personal challenge. Seventeen respondents $(35.4 \%)$ gave the highest score to the relationship between private entrepreneurship and social status as prestige (entrepreneurship can have a negative connotation due to recent scandals), and 22 respondents (45.8\%) reported having good experience in entrepreneurship. Twelve respondents $(25 \%)$ stated they independently 
ToSEE - Tourism in Southern and Eastern Europe, Vol. 6, pp. 725-737, 2021.

C. Stipanović, E. Rudan, V. Zubović: THE ENTREPRENEURIAL INTENTIONS OF TOURISM AND ...

studied examples of good practice. According to 20 students (41.7\%), new technologies are a positive, encouraging influence on starting a business.

According to the analysis, the second hypothesis can be accepted. Intrinsic motivation is the strongest predictor for entrepreneurial initiatives.

\subsection{Covid-19 pandemic and entrepreneurial initiatives}

New technologies are especially present in the face of the Covid-19 pandemic, when almost all business activities are conducted online and business operations are based on the use of technology.

In this respect, $29.2 \%$ of the respondents (14 students) reported that, should the Covid- 19 pandemic continue, they see it as an opportunity to focus their future entrepreneurial activity on online business, that is, they recognize the opportunity to realize their innovative entrepreneurial ideas. Redirecting the educational process to an online environment (elearning) has had a positive effect on the entrepreneurial intentions of both full-time and part-time students and has not impeded their entrepreneurial initiatives. Students are of the opinion that the changes Covid-19 has brought to their lives (no active socialization among the student population; students have to work on assignments alone and independently; fewer opportunities for connecting and making new friends) make it easier for them to develop their own ideas for entrepreneurial activity. Online teaching as a result of the Covid-19 pandemic has also had a positive effect on the level of acquired competencies for launching future entrepreneurial initiatives. This statement was rated with an average score of 3.6, on a 5-point Likert scale, ranging from $1=$ strongly disagree to $5=$ strongly agree.

Table 4: Level of issues negatively affecting motivation to start a business during the Covid-19 pandemic

\begin{tabular}{lcc}
\hline Issues & Aver. score & St.dev. \\
\hline Bureaucratic red tape in starting a business & 2,6 & 1,63 \\
Competition & 2,9 & 1,76 \\
Lack of funding & 2,4 & 1,7 \\
Global impact of the Covid-19 pandemic & 3,2 & 1,81 \\
Changes to legislative regulations & 2,9 & 1,62 \\
Uncertainty in entrepreneurial activity & 1,7 & 1,1 \\
Bureaucratic red tape in starting a business & 2,2 & 1,15 \\
\hline
\end{tabular}

Source: Authors' own elaboration.

Table 4. illustrates the level of issues that negatively impact motivation to start a business during the Covid-19 pandemic. The respondents were asked to rate the listed issues using a Likert scale, anchored at $1=$ least negative impact and $5=$ greatest negative impact. The entrepreneurial readiness of students reveals lack of funding to be the most important obstacle to starting a business, with the situation caused by the pandemic being in second place, suggesting that Covid-19 has an important but not decisive impact on launching an entrepreneurial initiative. Second place is also shared by "Bureaucratic red tape" although this largely refers to the students being poorly informed about or not being 
ToSEE - Tourism in Southern and Eastern Europe, Vol. 6, pp. 725-737, 2021.

C. Stipanović, E. Rudan, V. Zubović: THE ENTREPRENEURIAL INTENTIONS OF TOURISM AND ...

knowledgeable of the rules and regulations for starting a business. Students do not perceive as a high risk the possible changes to legislative regulations, mostly with regard to incentives for young entrepreneurs. Fear of competition holds the middle position among the issues affecting motivations, and calls for a well-conceived response in the form of a high level of innovativeness and the differentiation of new forms of entrepreneurial initiative that differ from those of competitors.

According to the obtained data and conducted analyzes, the hypothesis of a negative impact can be partially accepted. Namely, although respondents mostly agree with the statement about the negative impact of the Covid-19 pandemic on entrepreneurial initiatives, a greater obstacle is the sources of funding, and equally are the bureaucratic problems associated with the implementation of entrepreneurial initiative.

\section{CONCLUSION}

Encouraging entrepreneurial initiatives and fostering the development of entrepreneurship depends on the synergy of education, the economy, and policies (Triple Helix model). Entrepreneurship presents opportunities for the qualitative transformation of a poorly competitive economy into a burgeoning economy, based on the transfer on knowledge and by actively creating the future under digitalization, Industry 4.0 and Tourism 2.0. Encouraging the entrepreneurial initiatives of students through improvements to the educational systems paves the way to creative solutions and design thinking that will help valorize changes in the environment (by transforming the adverse effects of the pandemic and resulting crisis into opportunities) to generate novel directions of development.

This study focuses on the entrepreneurial intentions of final-year undergraduate students at the Faculty of Tourism and Hospitality Management. Results indicate that due to an unfavorable entrepreneurial climate and poor quality of life under Covid-19 a large percentage of the surveyed students intend to leave Croatia, with only one in five surveyed students $(20.6 \%)$ being interested in starting their own business (25.5\% of parttime students and $15.4 \%$ of full-time students). Personal challenge provides the greatest incentive to starting a new business, although the influence of the environment should not be neglected either, with the social and societal environment (family support and educational environment) playing the most important role according to the research results. The results of this study are consistent with the findings of previous research (Zampetakis et al. 2011; Koe et al. 2012; Lai 2020), confirming that young people are highly motivated by the need for self-actualization and the need for achievement in entrepreneurial initiatives.

The research accepted the hypotheses about the importance of the environment, and especially about the importance of personal challenge as a motivation for taking entrepreneurial initiatives.

The Covid-19 pandemic has affected the ease of starting and maintaining a business in an online environment. The study results indicate that while many respondents are motivated to engage in entrepreneurial activity, they do not see the Covid-19 crisis as the 
ToSEE - Tourism in Southern and Eastern Europe, Vol. 6, pp. 725-737, 2021.

C. Stipanović, E. Rudan, V. Zubović: THE ENTREPRENEURIAL INTENTIONS OF TOURISM AND ...

greatest constraint but rather the lack of funding, and bureaucratic red tape. It can also be concluded that certain socio-cultural characteristics, in particular the possibility of continuing the entrepreneurial activity of parents, friends or relatives, are strong incentives for students to pursue entrepreneurial activities in the future.

A drawback of this study was the too small population of full-time students, which made it necessary to expand the sample to include the entire populations of both full-time and part-time final-year undergraduate (fourth year) students, despite part-time students, due to their work experience, having different motivations for pursuing entrepreneurial activities than full-time students. It is recommended that future research should focus on examining the entrepreneurial initiatives of students in other study years and that comparisons should be made with the results of similar research at other faculties of economics.

\section{REFERENCES}

Arranz, N., Arroyabe, M. F. and Fdez de Arroyabe, J.C. (2019), "Entrepreneurial intention and obstacles of undergraduate students: the case of the universities of Andalusia", Studies in Higher Education, Vol. 44, No.11, pp. 2011-2024. https://doi.org/10.1080/03075079.2018.1486812

Bilić, I., Škokić, V. and Lovrinčević, M. (2021), “Academic Entrepreneurship in Post-transition CountryCase Study of Croatia”, J Knowl Econ, Vol. 12, pp. 41-55. https://doi.org/10.1007/s13132-0170452-6

Boldureanu, G., Ionescu, A.M., Bercu, A-M., Bedrule-Grigorută, M.V. and Boldureanu, D. (2020), "Entrepreneurship Education through Successful Entrepreneurial Models in Higher Education Institutions", Sustainability, Vol. 12, No. 3, 1267. https://doi.org/10.3390/su12031267

Bylund, P.L. and McCaffrey, M. (2017), "A theory of entrepreneurship and institutional uncertainty", Journal of Business Venturing, Vol. 32, No. 5, pp. 461-475. https://doi.org/10.1016/j.jbusvent.2017.05.006

Chlosta, S., Patzelt, H., Klein, S.B. and Dormann, C. (2012), "Parental role models and the decision to become self-employed: The moderating effect of personality”, Small Business Economics, Vol. 38, No. 1 , pp. 121-138. https://doi.org/10.1007/s11187-010-9270-y

Daim, T., Dabic, M. and Bayraktaroglu, E. (2016), "Students' entrepreneurial behavior: international and gender differences", Journal of Innovation and Entrepreneurship, Vol. 5, No. 19, pp. 1-22. https://doi.org/10.1186/s13731-016-0046-8

Dickel, P. and Eckardt, G. (2021), "Who wants to be a social entrepreneur? The role of gender and sustainability orientation”, Journal of Small Business Management, Vol. 59, No. 1, pp. 196-218 https://doi.org/10.1080/00472778.2019.1704489

Europska komisija (n.d.), Poduzetništvo u obrazovanju, viewed 21 April 2021, https://ec.europa.eu/education/policies/european-policy-cooperation/entrepreneurship-ineducation_hr

Farzin, F., Thomson, J., Dekkers, R. and Whittam, G. (2014), “An Investigation into the impact of technoentrepreneurship education on self-employment", in 23rd International Conference on Management of Technology (IAMOT 2014), Washington, USA. https://doi.org/10.5281/zenodo.1109329

Financijska agencija FINA, n.d., Udio žena u vlasničkoj strukturi trgovačkih društava u Hrvatskoj, viewed 02 May 2021, https://www.fina.hr/-/udio-zena-u-vlasnickoj-strukturi-trgovackih-drustava-uhrvatskoj-u- 2018.-godini-iznosi-31-3.

Gartner, W.B. (1990), "What are we talking about when we talk about entrepreneurship?”, Journal of Business Venturing, Vol. 5, No. 1, pp. 15-28.

Hassan, R.A. and Wafa, S.A. (2012), "Predictors towards entrepreneurial intention: a Malaysian case study", Asian Journal of Business and Management Sciences, Vol. 1, No. 11, pp. 1-10.

Koe, W.L., Sa'ari, J.R., Majid, I.A. and Ismail, K. (2012), "Determinants of entrepreneurial intention among millennial generation", Procedia-Social and Behavioral Sciences, Vol. 40, pp. 197-208. https://doi.org/10.1016/j.sbspro.2012.03.181 
ToSEE - Tourism in Southern and Eastern Europe, Vol. 6, pp. 725-737, 2021.

C. Stipanović, E. Rudan, V. Zubović: THE ENTREPRENEURIAL INTENTIONS OF TOURISM AND ...

Kourilsky, M.L. and Walstad, W.B. (1998), "Entrepreneurship and female youth: Knowledge, attitudes, gender differences, and educational practices". Journal of Business venturing, Vol. 13, No. 1, pp. 77-88. https://doi.org/10.1016/S0883-9026(97)00032-3

Krueger Jr, N.F., Reilly, M.D. and Carsrud, A.L. (2000), "Competing models of entrepreneurial intentions", Journal of business venturing, Vol. 15, No. 5, pp. 411-432. https://doi.org/10.1016/S08839026(98)00033-0

Lai, L S. and To, W.M. (2020), "E-Entrepreneurial intention among young Chinese adults", Asian Journal of Technology Innovation, Vol. 28, No. 1, pp. 119-137. ttps://doi.org/10.1080/19761597.2020.1713832

Langkamp Bolton, D. and Lane, M.D. (2012), "Individual entrepreneurial orientation: development of a measurement instrument", Education + Training, Vol. 54, No. 2/3, pp. 219-233. https://doi.org/10.1108/00400911211210314

Melugbo, D.U., Ogbuakanne, M.U. and Jemisenia, J.O. (2020), "Entrepreneurial potential self-assessment in times of COVID-19: Assessing readiness, engagement, motivations and limitations among young adults in Nigeria", Ianna Journal of Interdisciplinary Studies, Vol. 1, No. 2, pp. 12-28.

Mishra, C.S. and Zachary, R.K. (2015), "The Theory of Entrepreneurship", Entreprenurship research journal, Vol. 5, No. 4, pp. 251-268. https://doi.org/10.1515/erj-2015-0042

Naveed Iftikhar, M., Ahmad, M. and Audretsch, D.B. (2020), "The knowledge spillover theory of entrepreneurship: the developing country context", International Entrepreneurship and Management Journal, Vol. 16, pp. 1327-1346. https://doi.org/10.1007/s11365-020-00667-w

Oberman Peterka, S. (2011), "Entrepreneurial university as the most important leverage in achieving knowledge-based society" in Reić, Z. and Šimić, V., The Ninth International Conference: Challenges of Europe: Growth and Competitiveness - Reversing the Trends, Sveučilište u Splitu, Split, pp. 575-595.

Oberman Peterka, S., Singer, S. and Alpeza, M. (2013), "Poduzetničko obrazovanje-nedostajuća komponenta u stvaranju multidisciplinarnog integriranog sveučilišta”, in Čavrak, V. and Gelo, T., Ekonomsko obrazovanje u republici Hrvatskoj-jučer, danas, sutra, Ekonomski fakultet Sveučilišta u Zagrebu, Zagreb, pp. 279-301.

Parreira, P., Mónico, L., Carvalho, C. and Silva, A. (2018), "Entrepreneurship in higher education: The effect of academy, motivation, resources, incentives, and self-efficacy in the entrepreneurship potential", Entrepreneurship: Development Tendencies and Empirical Approach, pp. 329-350. https://doi.org/10.5772/intechopen.71695

Qiao, X. and Huang, J.H. (2019), "Effect of College Students' Entrepreneurial Self-Efficacy on Entrepreneurial Intention: Career Adaptability as a Mediating Variable”, International Journal of Educational Methodology, Vol. 5, No. 3, pp. 305-313. https://doi.org/10.12973/ijem.5.3.305

Shane, S.A. (2003), General theory of entrepreneurship. The individual opportunita nexus, Edwar Elgar, Cheltenham.

Singer, S. and Oberman Peterka, S. (2012), "Ocjena koncepta triple helix: kako testirati novi koncept sa starim pokazateljima”, Ekonomski pregled, Vol. 63, No. 11, pp. 608-626.

Staniewski, M.W. and Awruk, K. (2021), "Parental attitudes and entrepreneurial success", Journal of Business Research, Vol. 123, pp. 538-546. https://doi.org/10.1016/j.jbusres.2020.10.039

Škrtić, M. and Mikić, M. (2011), Poduzetništvo, Sinergija nakladništvo d.o.o., Zagreb.

Yao, X., Wu, X. and Long, D. (2016), "University students' entrepreneurial tendency in China: Effect of students' perceived entrepreneurial environment", Journal of Entrepreneurship in Emerging Economies, Vol. 8, No. 1, pp. 60-81. https://doi.org/10.1108/JEEE-03-2015-0021

Zampetakis, L.A., Gotsi, M., Andriopoulos, C. and Moustakis, V. (2011), "Creativity and entrepreneurial intention in young people: Empirical insights from business school students", The International Journal of Entrepreneurship and Innovation, Vol. 12, No. 3, pp. 189-199. https://doi.org./10.5367/ijei.2011.0037 
ToSEE - Tourism in Southern and Eastern Europe, Vol. 6, pp. 725-737, 2021.

C. Stipanović, E. Rudan, V. Zubović: THE ENTREPRENEURIAL INTENTIONS OF TOURISM AND ...

Christian Stipanović, Ph.D., Full professor with tenure

University of Rijeka, Faculty of Tourism and Hospitality Management

Primorska 46, 51410 Opatija, Croatia

+385-51-294-184

christis@fthm.hr

Elena Rudan, Ph.D., Associate professor

University of Rijeka, Faculty of Tourism and Hospitality Management

Primorska 46, 51410 Opatija, Croatia

+385-51-294-312

elenar@fthm.hr

Vedran Zubović, M.Sc. Assistant

University of Rijeka, Faculty of Tourism and Hospitality Management

Primorska 46, 51410 Opatija, Croatia

$+385-51-294-712$

vedranz@fthm.hr 